Prepared in cooperation with the Lake Champlain Basin Program and the Vermont Department of Environmental Conservation

\title{
Concentration and Flux of Total and Dissolved Phosphorus, Total Nitrogen, Chloride, and Total Suspended Solids for Monitored Tributaries of Lake Champlain, 1990-2012
}

Open-File Report 2014-1209

U.S. Department of the Interior

U.S. Geological Survey 



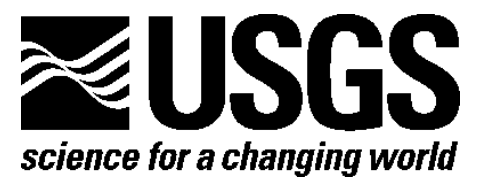

Prepared in cooperation with the Lake Champlain Basin Program and the Vermont Department of Environmental Conservation

\section{Concentration and Flux of Total and Dissolved Phosphorus, Total Nitrogen, Chloride, and Total Suspended Solids for Monitored Tributaries of Lake Champlain, 1990-2012}

By Laura Medalie

Open-File Report 2014-1209

U.S. Department of the Interior

U.S. Geological Survey 


\section{U.S. Department of the Interior \\ SALLY JEWELL, Secretary}

\section{U.S. Geological Survey \\ Suzette M. Kimball, Acting Director}

U.S. Geological Survey, Reston, Virginia: 2014

For more information on the USGS-the Federal source for science about the Earth, its natural and living resources, natural hazards, and the environment-visit

http://www.usgs.gov/ or call 1-888-ASK-USGS

For an overview of USGS information products, including maps, imagery, and publications, visit $h$ ttp://www.usgs.gov/pubprod/

To order this and other USGS information products, visit http://store.usgs.gov/

Any use of trade, firm, or product names is for descriptive purposes only and does not imply endorsement by the U.S. Government.

Although this information product, for the most part, is in the public domain, it also may contain copyrighted materials as noted in the text. Permission to reproduce copyrighted items must be secured from the copyright owner.

Suggested citation:

Medalie, Laura, 2014, Concentration and flux of total and dissolved phosphorus, total nitrogen, chloride, and total suspended solids for monitored tributaries of Lake Champlain, 1990-2012: U.S. Geological Survey Open-File Report 2014-1209, 21 p., http://dx.doi.org/10.3133/ofr20141209.

ISSN 2331-1258 (online) 


\section{Acknowledgments}

The author acknowledges staff from Vermont and New York state agencies who collect, analyze, ensure the quality of, and post the water-quality data, including Dan McAvinney, Dan Needham, Angela Shambaugh, Eric Smeltzer, and Peter Stangel of the Vermont Department of Environmental Conservation, and Fred Dunlap of the New York State Department of Environmental Conservation. Also, thanks are extended to Marc Simoneau from the Quebec Ministry of Sustainable Development, Environmental and the Fight against Climate Change for explaining changes to the Pike River streamgage. Eric Howe from the Lake Champlain Basin Program helped administer this project. 


\section{Contents}

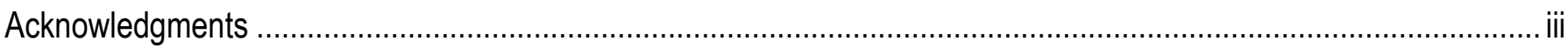

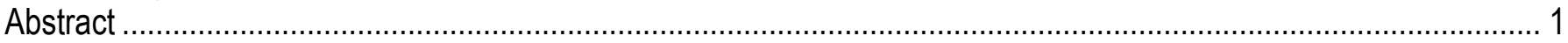

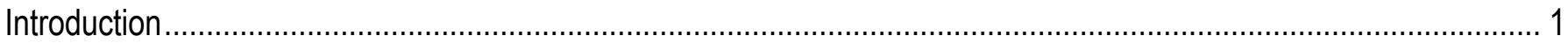

Methods

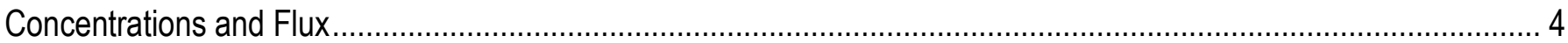

Summary

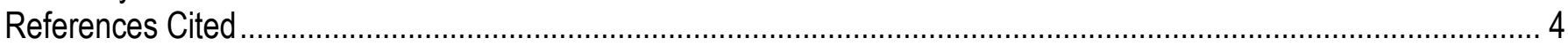

Appendix 1. Annual Mean Concentration and Total Annual Flux of Estimated and Flow-Normalized Total Phosphorus, Dissolved Phosphorus, Total Nitrogen, Chloride, and Total Suspended Solids in 18 Monitored Tributaries of Lake

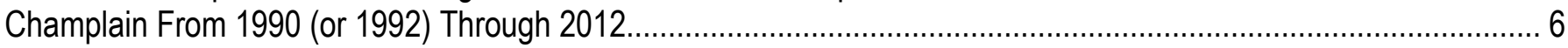

Appendix 2. Daily Estimated and Flow-Normalized Concentration and Flux of Total Phosphorus in 18 Monitored Tributaries of Lake Champlain From 1990 Through 2012 ……................................................................. 6 Appendix 3. Daily Estimated and Flow-Normalized Concentration and Flux of Dissolved Phosphorus in 18 Monitored Tributaries of Lake Champlain From 1990 Through 2012.

Appendix 4. Daily Estimated and Flow-Normalized Concentration and Flux of Total Nitrogen in 18 Monitored

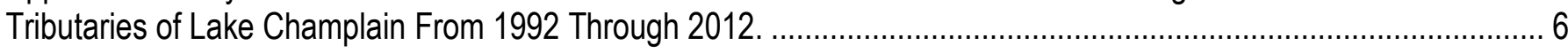

Appendix 5. Daily Estimated and Flow-Normalized Concentration and Flux of Chloride in 18 Monitored Tributaries of

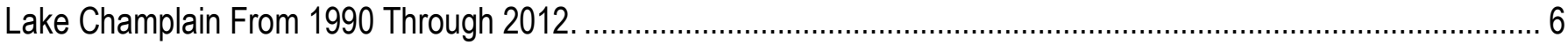
Appendix 6. Daily Estimated and Flow-Normalized Concentration and Flux of Total Suspended Solids in 18 Monitored Tributaries of Lake Champlain From 1992 Through 2012 .......................................................................... 6

\section{Figures}

Figure 1. Map showing Lake Champlain Basin, water-quality monitoring stations and streamgages, and boundaries of the monitored basins of tributaries to Lake Champlain. Figure modified from Medalie (2013)............................... 7

Figure 2. Plots showing estimated flux in relation to observed flux for $A$, model using all observations and $B$, model excluding extreme observation on November 9, 1996, and $C$, differences in annual estimated flux and flow-normalized annual flux for models including and excluding the extreme 1996 observation, for total suspended solids for the

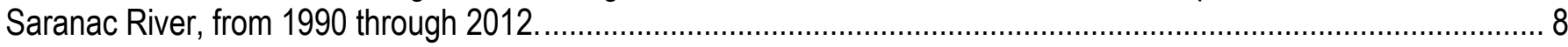

Figure 3. Graphs showing annual estimated (brown dots) and flow-normalized (green lines) concentrations of total phosphorus for the 18 monitored tributaries of Lake Champlain from 1990 through 2012. The y-axis scale for the LaPlatte River plot is different than the rest of the plots.

Figure 4. Graphs showing annual estimated (brown dots) and flow-normalized (green lines) concentrations of dissolved phosphorus for the 18 monitored tributaries of Lake Champlain from 1990 through 2012. The y-axis scale for the LaPlatte River plot is different than the rest of the plots

Figure 5. Graphs showing annual estimated (brown dots) and flow-normalized (green lines) concentrations of total nitrogen for the 18 monitored tributaries of Lake Champlain from 1992 through 2012

Figure 6. Graphs showing annual estimated (brown dots) and flow-normalized (green lines) concentrations of chloride for the 18 monitored tributaries of Lake Champlain from 1990 through 2012. The $y$-axis scale for the LaPlatte River plot is different than the rest of the plots.

Figure 7. Graphs showing annual estimated (brown dots) and flow-normalized (green lines) concentrations of total suspended solids for the 18 monitored tributaries of Lake Champlain from 1992 through 2012................................ 13 
Figure 8. Graphs showing annual estimated (brown dots) and flow-normalized (green lines) flux of total phosphorus for the 18 monitored tributaries of Lake Champlain from 1990 through 2012. The y-axis scales for the shaded plots are different than the rest of the plots.

Figure 9. Graphs showing annual estimated (brown dots) and flow-normalized (green lines) flux of dissolved phosphorus for the 18 monitored tributaries of Lake Champlain from 1990 through 2012.

Figure 10. Graphs showing annual estimated (brown dots) and flow-normalized (green lines) flux of total nitrogen for the 18 monitored tributaries of Lake Champlain from 1992 through 2012. The y-axis scales for the shaded plots are different than the rest of the plots.

Figure 11. Graphs showing annual estimated (brown dots) and flow-normalized (green lines) flux of chloride for the 18 monitored tributaries of Lake Champlain from 1990 through 2012. The y-axis scale for the Winooski River plot is different than the rest of the plots.

Figure 12. Graphs showing annual estimated (brown dots) and flow-normalized (green lines) flux of total suspended solids for the 18 monitored tributaries of Lake Champlain from 1992 through 2012. The y-axis scales for the shaded plots are different than the rest of the plots.

\section{Tables}

Table 1. Streamgage and water-quality monitoring station numbers and drainage areas for tributaries to Lake Champlain.

Table 2. Half-window widths for parameters of the Weighted Regression on Time, Discharge, and Season (WRTDS) regression model used to estimate concentration and flux of total and dissolved phosphorus, total nitrogen, chloride, and total suspended solids for tributaries to Lake Champlain.

Table 3. Flux bias statistics comparing the Weighted Regressions on Time, Discharge, and Season regression model estimates with water-quality observations for total and dissolved phosphorus, total nitrogen, chloride, and total suspended solids for tributaries to Lake Champlain. 


\section{Conversion Factors}

SI to Inch/Pound

\begin{tabular}{|c|c|c|}
\hline Multiply & By & To obtain \\
\hline \multicolumn{3}{|c|}{ Length } \\
\hline kilometer $(\mathrm{km})$ & 0.6214 & mile (mi) \\
\hline \multicolumn{3}{|c|}{ Area } \\
\hline square kilometer $\left(\mathrm{km}^{2}\right)$ & 0.3861 & square mile $\left(\mathrm{mi}^{2}\right)$ \\
\hline \multicolumn{3}{|c|}{ Flow rate } \\
\hline cubic meter per second $\left(\mathrm{m}^{3} / \mathrm{s}\right)$ & 35.31 & cubic foot per second $\left(\mathrm{ft}^{3} / \mathrm{s}\right)$ \\
\hline \multicolumn{3}{|c|}{ Mass } \\
\hline kilogram (kg) & 2.205 & pound avoirdupois (lb) \\
\hline $\begin{array}{l}\text { megagram }(\mathrm{Mg}) \text {; also known as metric ton } \\
(\mathrm{t})\end{array}$ & 1.102 & ton, short $(2,000 \mathrm{lb})$ \\
\hline metric ton per year & 1.102 & ton per year (ton/yr) \\
\hline
\end{tabular}

\section{Datum and Supplemental Information}

Horizontal coordinate information is referenced to the North American Datum of 1983 (NAD 83).

Concentrations of chemical constituents in water are given in milligrams per liter (mg/L).

\section{Abbreviations}

DP

MENV

TN

TP

TSS

USGS

WRTDS dissolved phosphorus

Ministry of the Environment

total nitrogen

total phosphorus

total suspended solids

U.S. Geological Survey

Weighted Regressions on Time, Discharge, and Season regression model 


\title{
Concentration and Flux of Total and Dissolved Phosphorus, Total Nitrogen, Chloride, and Total Suspended Solids for Monitored Tributaries of Lake Champlain, 1990-2012
}

\author{
By Laura Medalie
}

\begin{abstract}
Annual and daily concentrations and fluxes of total and dissolved phosphorus, total nitrogen, chloride, and total suspended solids were estimated for 18 monitored tributaries to Lake Champlain by using the Weighted Regressions on Time, Discharge, and Seasons regression model. Estimates were made for 21 or 23 years, depending on data availability, for the purpose of providing timely and accessible summary reports as stipulated in the 2010 update to the Lake Champlain "Opportunities for Action" management plan. Estimates of concentration and flux were provided for each tributary based on (1) observed daily discharges and (2) a flow-normalizing procedure, which removed the random fluctuations of climate-related variability. The flux bias statistic, an indicator of the ability of the Weighted Regressions on Time, Discharge, and Season regression models to provide accurate representations of flux, showed acceptable bias (less than \pm 10 percent) for 68 out of 72 models for total and dissolved phosphorus, total nitrogen, and chloride. Six out of 18 models for total suspended solids had moderate bias (between 10 and 30 percent), an expected result given the frequently nonlinear relation between total suspended solids and discharge. One model for total suspended solids with a very high bias was influenced by a single extreme value; however, removal of that value, although reducing the bias substantially, had little effect on annual fluxes.
\end{abstract}

\section{Introduction}

The 2010 update to the Lake Champlain “Opportunities for Action” management plan (Lake Champlain Basin Program, 2014) identifies several objectives related to reducing contamination from phosphorus, toxic substances, and pathogens in the Lake Champlain Basin. Production of timely and accessible summary reports, identified as one of the strategies for implementing the "Opportunities for Action” plan (Lake Champlain Basin Program, 2014, sec. 2.2), is addressed directly by this report. By providing estimates of fluxes of total phosphorus (TP), this report delivers the means for assessing progress towards the goal of reducing phosphorus flux in the basin. Estimates of concentrations and fluxes of total suspended solids (TSS), not previously evaluated using the Weighted Regressions on Time, Discharge, and Season (WRTDS) regression model (Hirsch and others, 2010), provide an indicator of transport for many substances (toxic and otherwise) that move through a drainage basin by means of attachment to the suspended particles. The other parameters evaluated in this report, dissolved 
phosphorus, total nitrogen, and chloride, are not mentioned specifically in the "Opportunities for Action" or other management documents but could be of interest to scientific or planning communities.

This report is an update of two previous U.S. Geological Survey (USGS) reports that used WRTDS (Hirsch and others, 2010) for estimating concentrations and loads in the 18 monitored Lake Champlain tributaries. The first report evaluated TP and total nitrogen (TN) from 1990 through 2009 (Medalie and others, 2012). The second report evaluated TP, TN, dissolved phosphorus (DP), and chloride from 2009 through 2011 (Medalie, 2013). The current report evaluates TP, TN, DP, chloride, and is expanded to include TSS concentrations. WRTDS is a method of estimating water-quality concentration and flux that overcomes many of the limitations of previous estimation methods (Moyer and others, 2012; Hirsch, 2014). A major feature of WRTDS is the provision of flow-normalized estimates of concentrations and fluxes, whereby the variability in water-quality conditions that is directly related to random variations in discharge is removed. Estimates of concentration or flux are commonly used as input to water-quality or other ecological models. Long-term datasets, such as this one for Lake Champlain, are used for climate-related modeling efforts, for comparing water-quality conditions to standards and criteria for regulatory purposes, or for assessing water-quality changes over time in the watershed.

To address the need to provide timely and accessible summary reports to the community of Lake Champlain Basin stakeholders, the USGS, in cooperation with the Lake Champlain Basin Program and the Vermont Department of Environmental Conservation, used WRTDS and available streamflow and concentration data to estimate daily and annual concentrations and fluxes of TP, DP, TN, chloride, and TSS for the 18 monitored tributaries to Lake Champlain (fig. 1; table 1). As determined by the availability of concentration data, daily and annual concentrations and fluxes of TP, DP, and chloride are provided for calendar years 1990 through 2012; and daily and annual concentrations and fluxes of TN and TSS are provided for calendar years 1992 through 2012.

\section{Methods}

The WRTDS regression model produces two kinds of concentration and flux estimates: one based on observed discharges and the other based on flow-normalized discharges (Hirsch and others, 2010). The flow-normalized estimate for a given date is an average estimate of concentration or flux that would be made if all of the observed discharges for that date were equally likely to have occurred. Flow-normalized estimates can be used to evaluate the effectiveness of watershed management actions with the effects of annual hydrologic variations mathematically removed.

Details of data collection, data analysis, and the application of WRTDS specifically to Lake Champlain tributary data are documented in Medalie (2013). Water-quality data were retrieved from the Vermont Department of Environmental Conservation (2013) Web site. Daily discharge data for streamgages on the 17 tributaries from the U.S. National Water Information System network were obtained from the U.S. Geological Survey (2014). Daily discharge data for the Pike River streamgages in Canada were obtained from the Centre d'Expertise Hydrique Québec (2014).

Estimates of concentrations and fluxes for the Little Ausable and Poultney Rivers are not presented for days with mean discharges greater than the highest sampled discharge because those days are beyond the valid range of extrapolation of the WRTDS model (Medalie, 2013). For years with unestimated days, annual values are flagged with a greater than $(>)$ remark. User-assigned half-window widths for the regression variables (time, discharge, and season), which inform weights used in the WRTDS regression equations, are shown in table 2. The default half-window widths (10 years for time, two logarithm cycles for discharge, and 0.5 year for season) were changed if model-checking 
diagnostics indicated that greater widths provided a better model fit. A detailed discussion of the effect of half-window widths on the WRTDS models is provided by Hirsch and others (2010).

A measure of the ability of WRTDS to predict the true flux is provided by the flux bias statistic, calculated as [mean (predicted flux) - mean(observed flux)] / mean (observed flux). A flux bias statistic of zero indicates an unbiased model; acceptable bias is defined as \pm 0.1 , or 10 percent (Hirsch, 2014). Flux bias statistics greater than zero indicate that the model estimates of flux generally are greater than observed fluxes, and values less than zero indicate the model's tendency to underpredict observed fluxes. All of the Lake Champlain tributaries had flux bias statistics of less than \pm 0.1 for TN and chloride, and only 2 out of 18 tributaries had flux bias statistics greater than \pm 0.1 for each of TP and DP; thus, 68 out of 72 models for these four constituents had acceptable bias (table 3 ).

For TSS, 11 tributaries had flux bias statistics less than $0.1 ; 6$ out of the 7 remaining tributaries had flux bias statistics less than 0.3. The large number of tributaries with flux bias statistics greater than 0.1 is not a particular concern because poorer model representations for TSS compared to other constituents are expected because of the highly nonlinear relation between TSS and discharge (Hirsch, 2014). However, one of these tributaries, the Saranac River, has a greater magnitude of potential bias than the others. When all recorded observations are used in the WRTDS model (fig. 2A), the flux bias statistic is -0.839 , and the model is seen to severely underestimate the extreme observation of November 9, 1996 (the date of the largest maximum of daily mean discharges, 10,200 cubic feet per second, for the period of record). The WRTDS model without the extreme observation (fig. 2B) yields a flux bias statistic $(-0.135)$ that is much closer to many of the other TSS flux bias statistics (table 3 ) and a plot in which all points of estimated versus observed concentrations are relatively close to the 1:1 line.

However, the November 1996 observed TSS concentration is needed in the model, despite the poor fit, because even underestimated, the observation still provides the higher 1996 estimate of flux (fig. 2C; appendix 1; 18.3 million kilograms per year (Mkg/yr) compared with $9.3 \mathrm{Mkg} / \mathrm{yr}$ for models with and without the observation). The complete time series of annual estimates (fig. 2C) puts the effect of the biased model in perspective; those based on observed discharges (points) for 1996 differ by a factor of 2 when models are run with and without the extreme 1996 observation. The effect of the extreme value lingers into 1997 because the November 1996 observation is close enough to 1997 to render as influential the seasonal component of weight on the regression. However, differences in annual estimates are negligible in all other years. The powerful ability of flow normalization to smooth effects of year-to-year variations and extreme values is illustrated by noting that the two lines in figure $2 \mathrm{C}$ representing flow-normalized estimates exhibit very little difference in all years, with differences converging towards zero as time advances from 1996.

The only change in method since previous publications is that streamgage 030420 on the Pike River in Canada that was used previously was discontinued in July 2012 and replaced by Canadian streamgage 030424 further downstream on the Pike River (operational since November 1, 2001). Daily discharge data from station 030420 for January 1, 1990, through October 31, 2001, were multiplied by the drainage-area ratio between the two stations (404 square kilometers $\left[\mathrm{km}^{2}\right]$ for 030420 and $584 \mathrm{~km}^{2}$ for 030424) in order to estimate daily discharges for station 030424 for the record prior to November 1 , 2001. Because of the larger drainage area and greater discharges at the Pike River streamgage used for this report compared with previous reports, load estimates for the Pike River for the record since 1990 are larger than those previously reported (Medalie and others, 2012; Medalie, 2013). 


\section{Concentrations and Flux}

Annual estimated and flow-normalized concentrations and fluxes of TP, DP, and chloride for 1990 through 2012 and of TN and TSS for 1992 through 2012 were calculated for the 18 monitored tributaries of Lake Champlain (figs. 3 through 7 [concentrations] and figs. 8 through 12 [fluxes]; appendix 1). For the same time periods, daily estimated and flow-normalized concentrations and fluxes of TP, DP, TN, chloride, and TSS also were calculated (appendixes 2 through 6).

\section{Summary}

The 2010 update to the Lake Champlain “Opportunities for Action" management plan includes strategies for implementing actions for reducing the flux of phosphorus and toxic substances and pathogens into Lake Champlain. One of the strategies is to provide timely and accessible summary reports. To address the need for summary reports, the U.S. Geological Survey, in cooperation with the Lake Champlain Basin Program and the Vermont Department of Environmental Conservation, used a regression-based method to estimate annual and daily concentrations and fluxes of total and dissolved phosphorus, total nitrogen, chloride, and total suspended solids for 18 monitored tributaries to Lake Champlain. Estimates were made on the basis of observed daily discharges and by using a flownormalizing procedure, which removed the variability in water-quality conditions that is directly related to random variations in discharge.

The flux bias statistic provides a measure of the ability of the regression models to accurately predict flux. Sixty-eight out of 72 regression models for the 18 tributaries for total and dissolved phosphorus, total nitrogen, and chloride had acceptable bias (less than 10 percent). Seven of the 18 regression models for total suspended solids had flux bias of greater than 0.1 , as expected, because of the highly nonlinear relation with discharge.

\section{References Cited}

Centre d'expertise hydrique Québec, 2014, Fiche signalétique de la station 030424: Centre d'expertise hydrique Québec Hydrometric Network level and flow history station database, accessed April 18, 2014, at

http://www.cehq.gouv.qc.ca/hydrometrie/historique donnees/fiche_station.asp?NoStation=030424.

Hirsch, R.M., 2014, Large biases in regression-based constituent flux estimates - Causes and diagnostic tools: Journal of the American Water Resources Association (JAWRA), paper JAWRA-13-0194-P, 24 p., accessed May 22, 2014, at http://dx.doi.org/10.1111/jawr.12195.

Hirsch, R.M., Moyer, D.L., and Archfield, S.A., 2010. Weighted regressions on time, discharge, and season (WRTDS) with an application to Chesapeake Bay river inputs: Journal of the American Water Resources Association (JAWRA), v. 46, no. 5, p. 857-880, accessed October 30, 2012, at http://onlinelibrary.wiley.com/doi/10.1111/j.1752-1688.2010.00482.x/abstract.

Lake Champlain Basin Program, 2014, Opportunities for action-An evolving plan for the future of the Lake Champlain Basin: Lake Champlain Basin Program Web page, accessed April 28, 2014, at http://plan.lcbp.org/.

Medalie, Laura, 2013, Concentration, flux, and the analysis of trends of total and dissolved phosphorus, total nitrogen, and chloride in 18 tributaries to Lake Champlain, Vermont and New York, 1990-2011: U.S. Geological Survey Scientific Investigations Report 2013-5021, 29 p. [Also available at http://pubs.usgs.gov/sir/2013/5021/.] 
Medalie, Laura, Hirsch, R.M., and Archfield, S.A., 2012, Use of flow-normalization to evaluate nutrient concentration and flux changes in Lake Champlain tributaries, 1990-2009: Journal of Great Lakes Research, v. 38, supplement 1, p. 58-67.

Moyer, D.L., Hirsch, R.M., and Hyer, K.E., 2012, Comparison of two regression-based approaches for determining nutrient and sediment fluxes and trends in the Chesapeake Bay watershed: U.S. Geological Survey Scientific Investigations Report 2012-5244, 118 p. [Also available at http://pubs.usgs.gov/sir/2012/5244/.]

U.S. Geological Survey, 2014, USGS current water data for the nation: U.S. Geological Survey National Water Information System Web database, accessed April 18, 2014, at http://waterdata.usgs.gov/nwis/rt.

Vermont Department of Environmental Conservation, 2013, Lake Champlain long-term monitoringTributary monitoring: Vermont Department of Environmental Conservation Lake Champlain longterm monitoring database, accessed November 15, 2013, at https://anrweb.vermont.gov/dec/dec/LongTermMonitoringTributary.aspx. 


\section{Appendixes}

\section{Available separately at http://pubs.usgs.gov/of/2014/1209/}

Appendix 1. Annual Mean Concentration and Total Annual Flux of Estimated and Flow-Normalized Total Phosphorus, Dissolved Phosphorus, Total Nitrogen, Chloride, and Total Suspended Solids in 18 Monitored Tributaries of Lake Champlain From 1990 (or 1992) Through 2012.

Appendix 2. Daily Estimated and Flow-Normalized Concentration and Flux of Total Phosphorus in 18 Monitored Tributaries of Lake Champlain From 1990 Through 2012.

Appendix 3. Daily Estimated and Flow-Normalized Concentration and Flux of Dissolved Phosphorus in 18 Monitored Tributaries of Lake Champlain From 1990 Through 2012.

Appendix 4. Daily Estimated and Flow-Normalized Concentration and Flux of Total Nitrogen in 18 Monitored Tributaries of Lake Champlain From 1992 Through 2012.

Appendix 5. Daily Estimated and Flow-Normalized Concentration and Flux of Chloride in 18 Monitored Tributaries of Lake Champlain From 1990 Through 2012.

Appendix 6. Daily Estimated and Flow-Normalized Concentration and Flux of Total Suspended Solids in 18 Monitored Tributaries of Lake Champlain From 1992 Through 2012. 


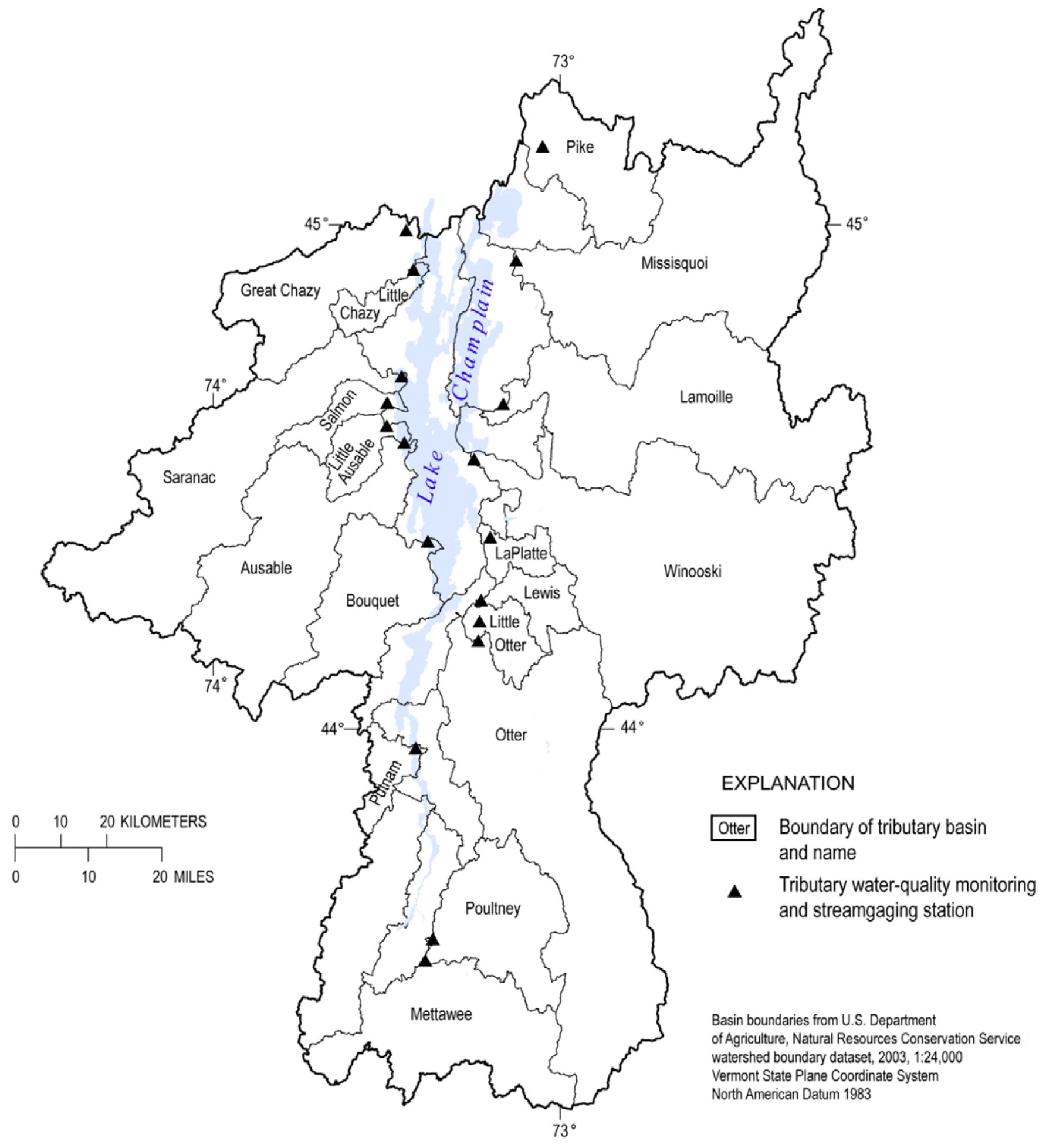

Figure 1. Map showing Lake Champlain Basin, water-quality monitoring stations and streamgages, and boundaries of the monitored basins of tributaries to Lake Champlain. Figure modified from Medalie (2013). 

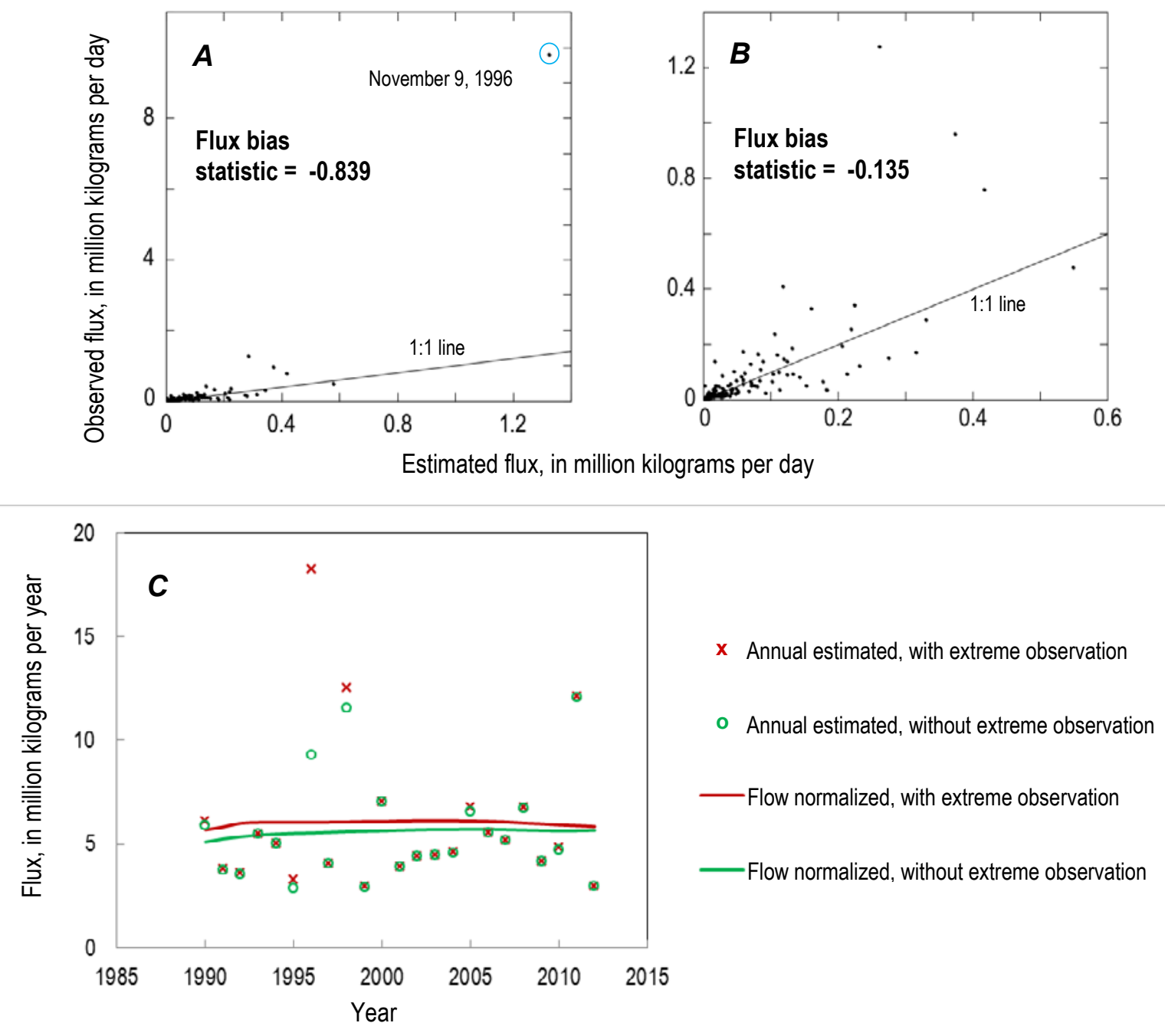

Figure 2. Plots showing estimated flux in relation to observed flux for $A$, model using all observations and $B$, model excluding extreme observation on November 9,1996 , and $C$, differences in annual estimated flux and flow-normalized annual flux for models including and excluding the extreme 1996 observation, for total suspended solids for the Saranac River, from 1990 through 2012. 

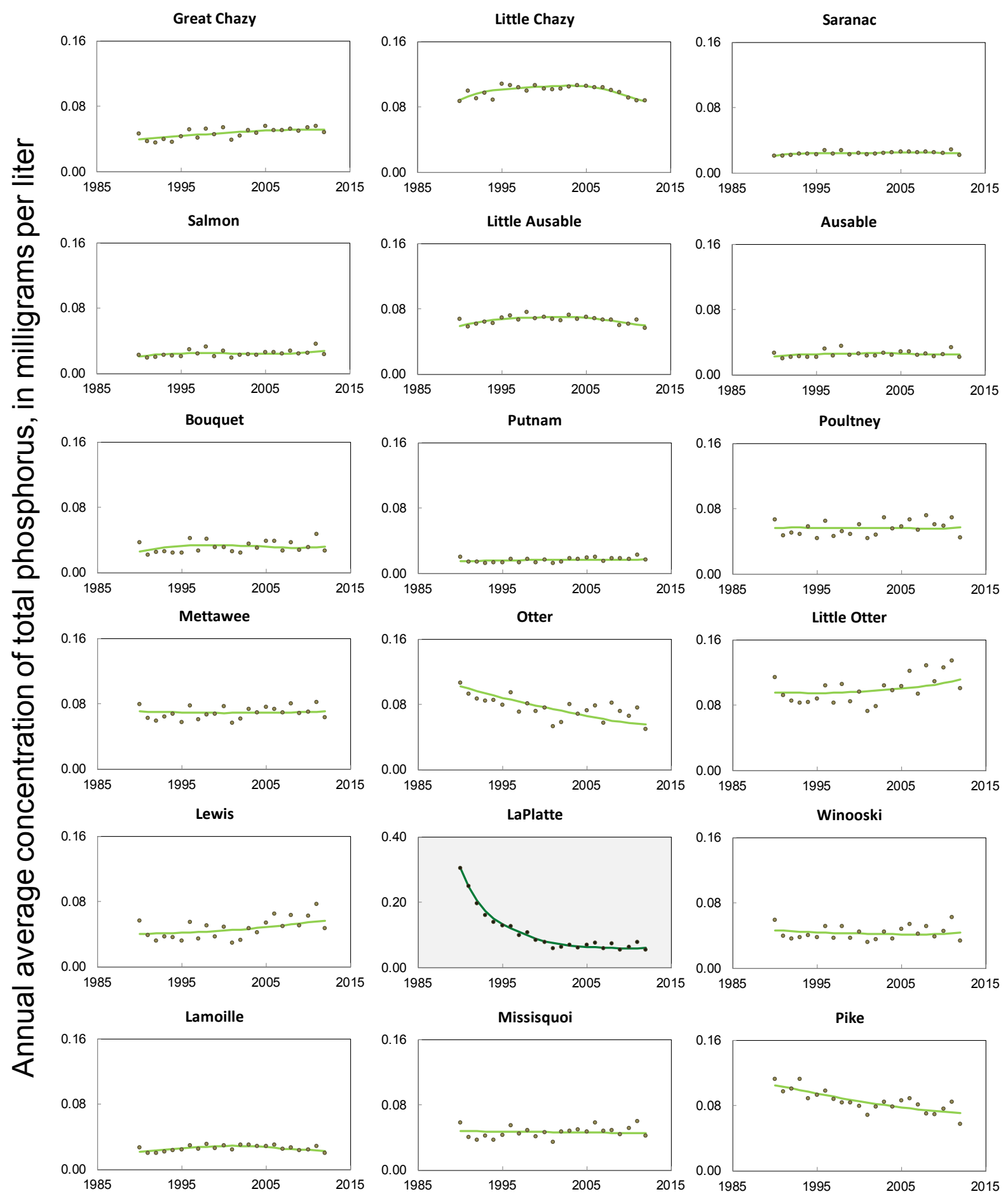

Figure 3. Graphs showing annual estimated (brown dots) and flow-normalized (green lines) concentrations of total phosphorus for the 18 monitored tributaries of Lake Champlain from 1990 through 2012. The y-axis scale for the LaPlatte River plot is different than the rest of the plots. 

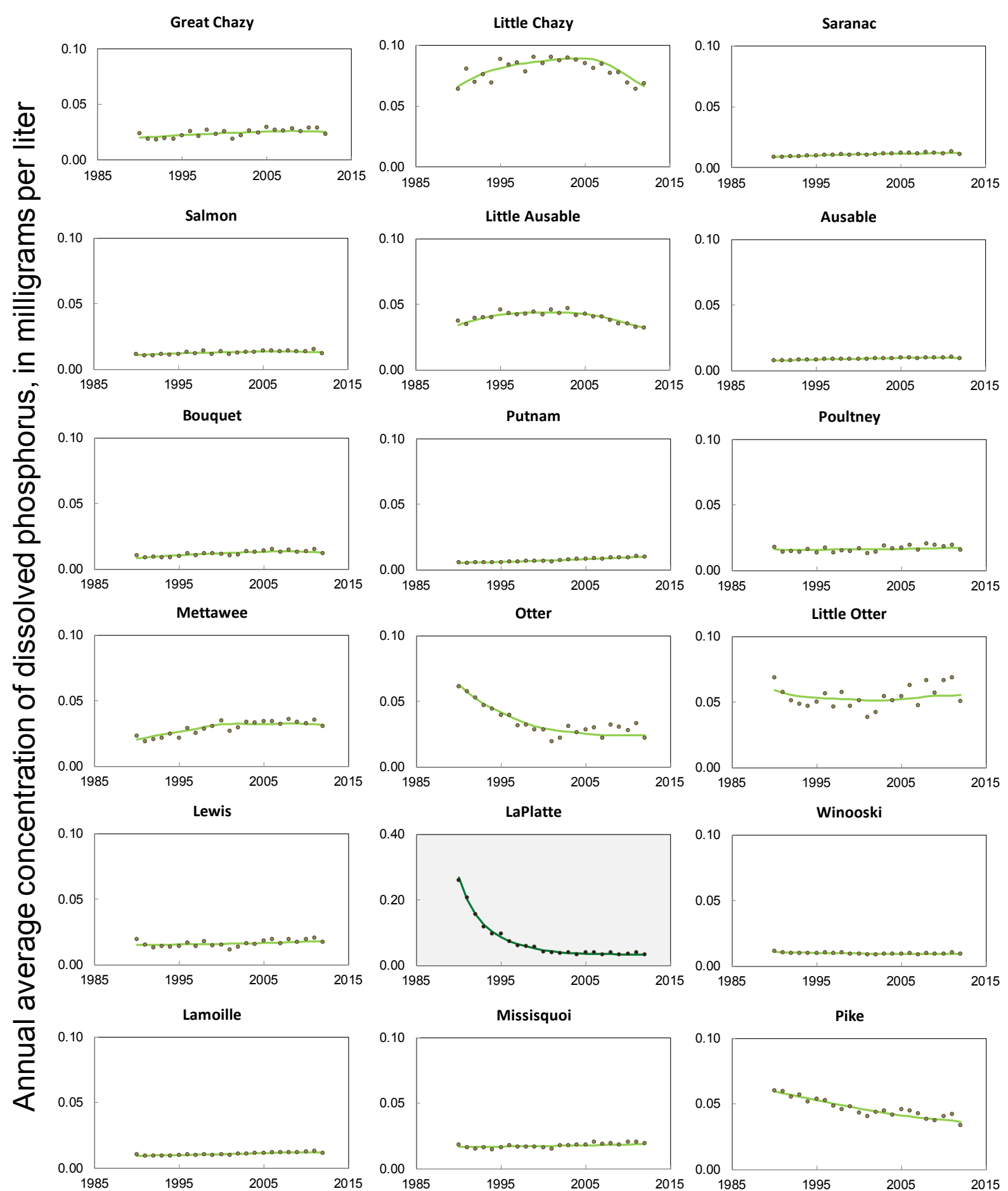

Figure 4. Graphs showing annual estimated (brown dots) and flow-normalized (green lines) concentrations of dissolved phosphorus for the 18 monitored tributaries of Lake Champlain from 1990 through 2012. The y-axis scale for the LaPlatte River plot is different than the rest of the plots. 

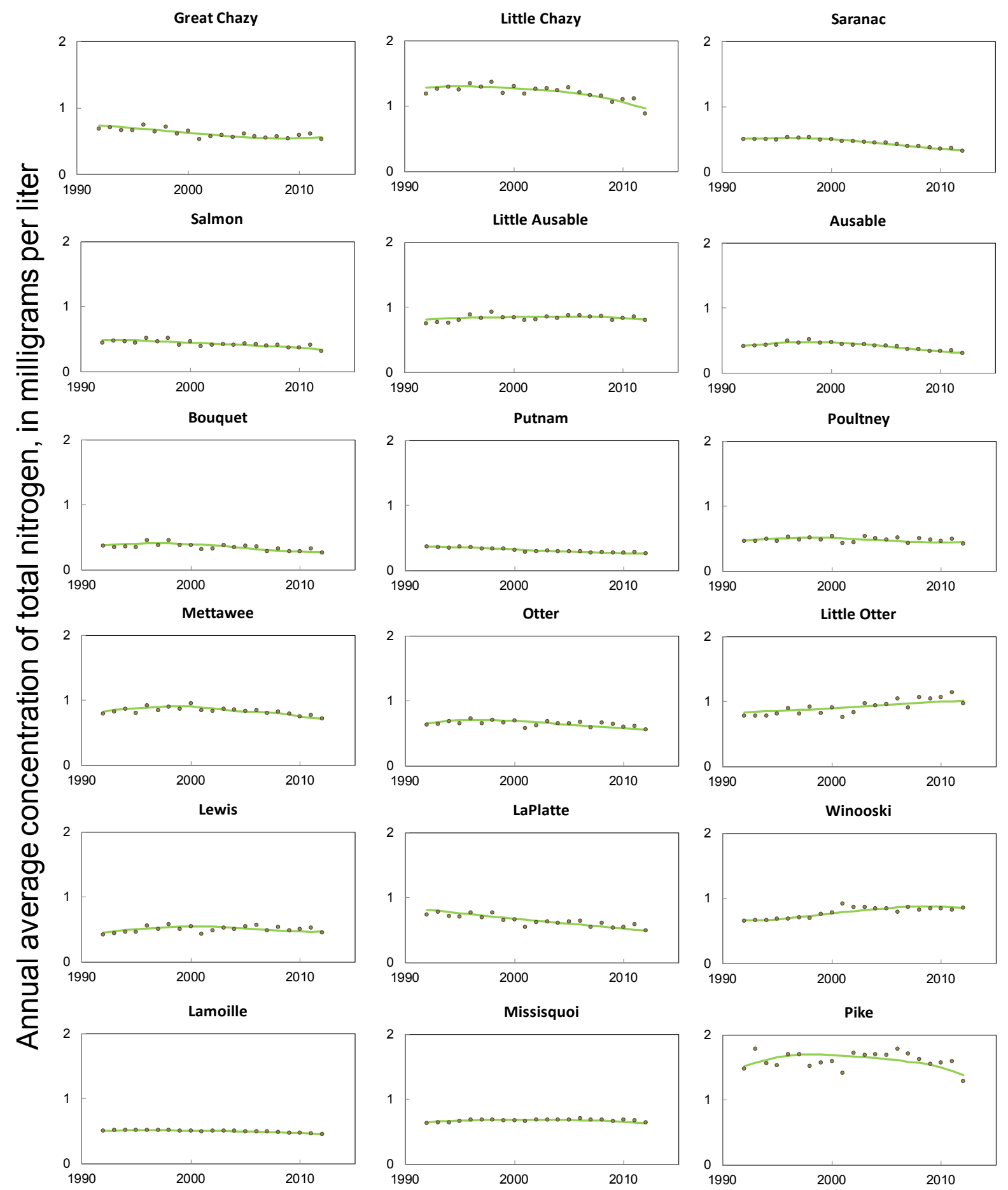

Figure 5. Graphs showing annual estimated (brown dots) and flow-normalized (green lines) concentrations of total nitrogen for the 18 monitored tributaries of Lake Champlain from 1992 through 2012 

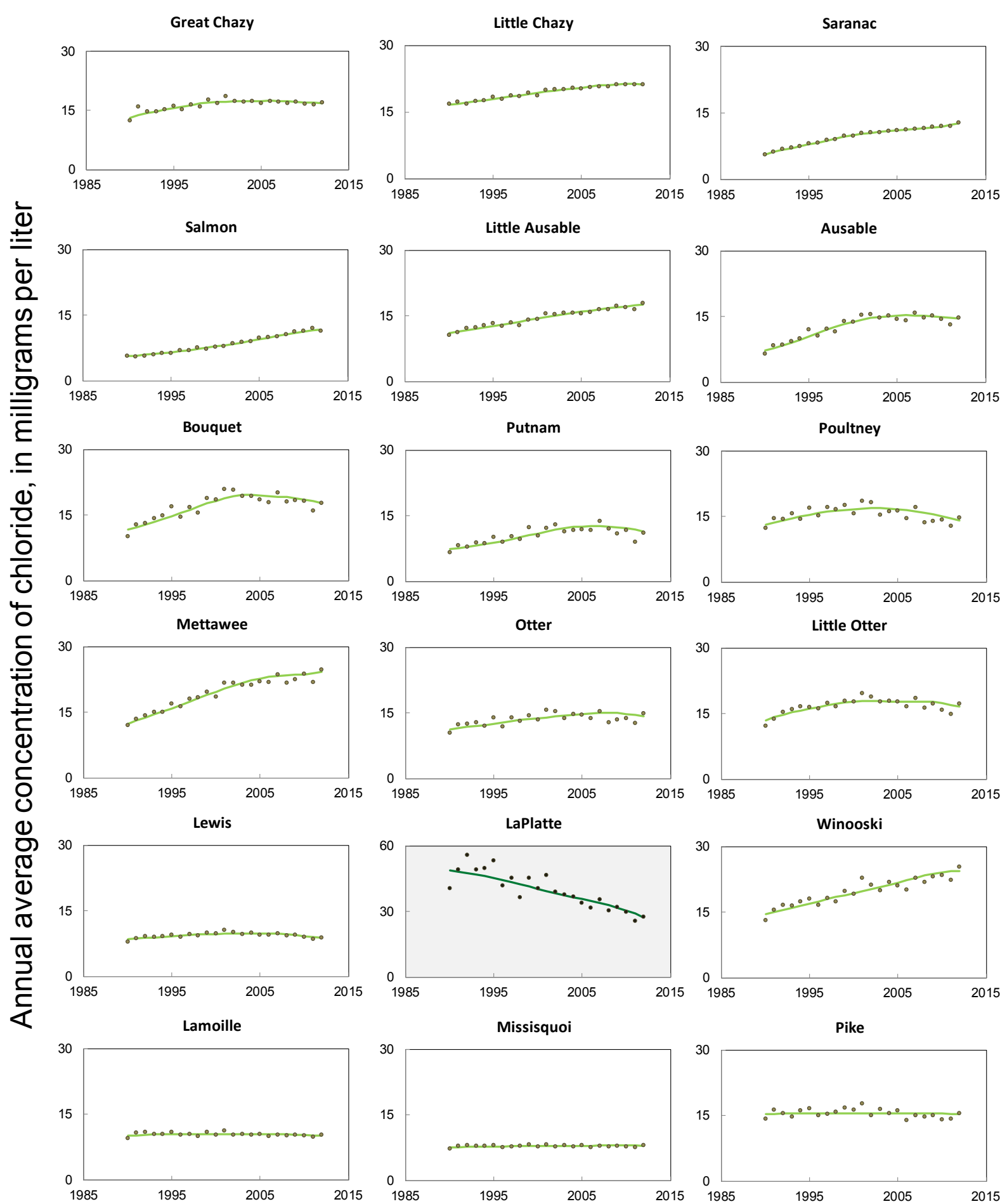

Figure 6. Graphs showing annual estimated (brown dots) and flow-normalized (green lines) concentrations of chloride for the 18 monitored tributaries of Lake Champlain from 1990 through 2012. The y-axis scale for the LaPlatte River plot is different than the rest of the plots. 

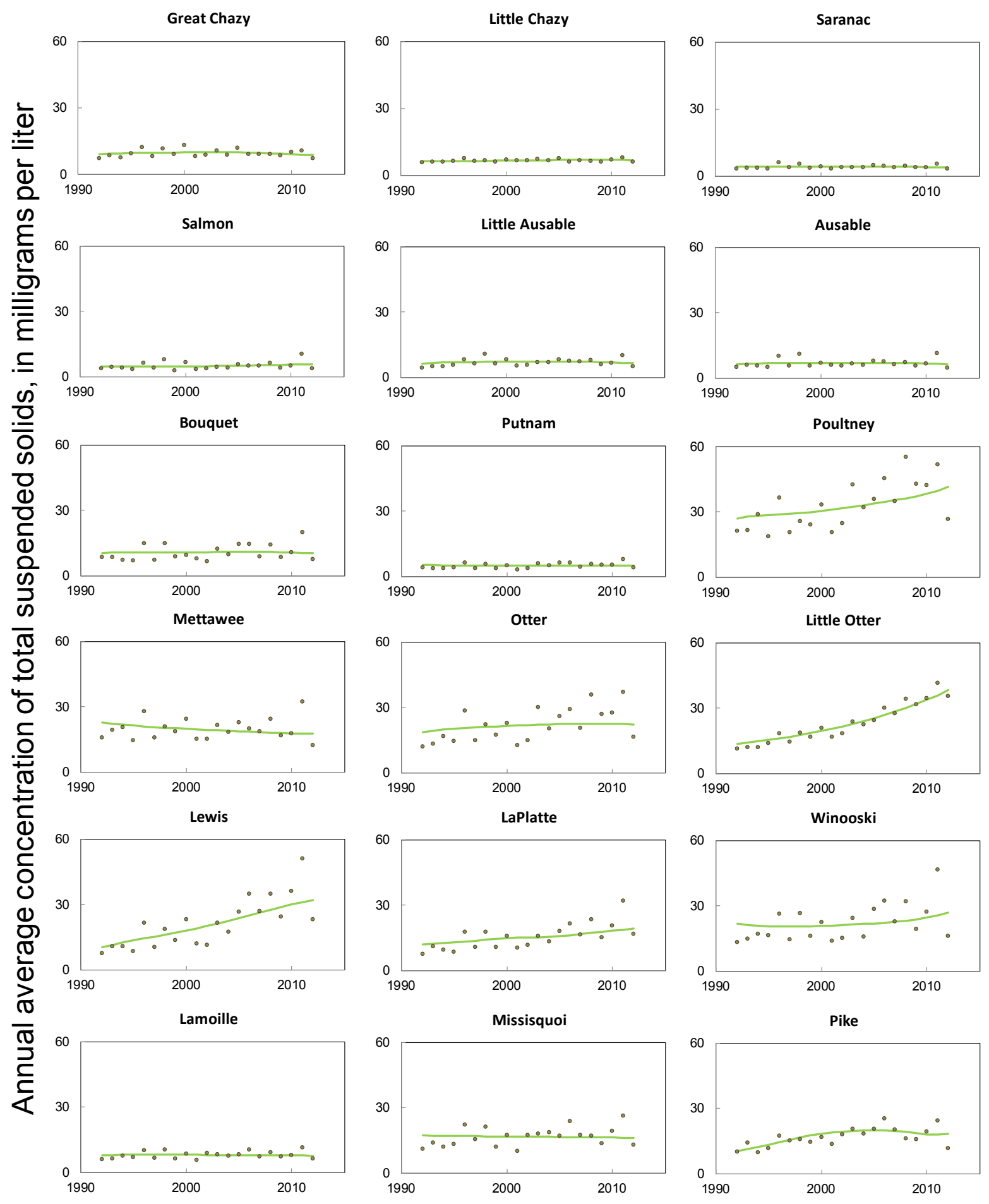

Figure 7. Graphs showing annual estimated (brown dots) and flow-normalized (green lines) concentrations of total suspended solids for the 18 monitored tributaries of Lake Champlain from 1992 through 2012. 

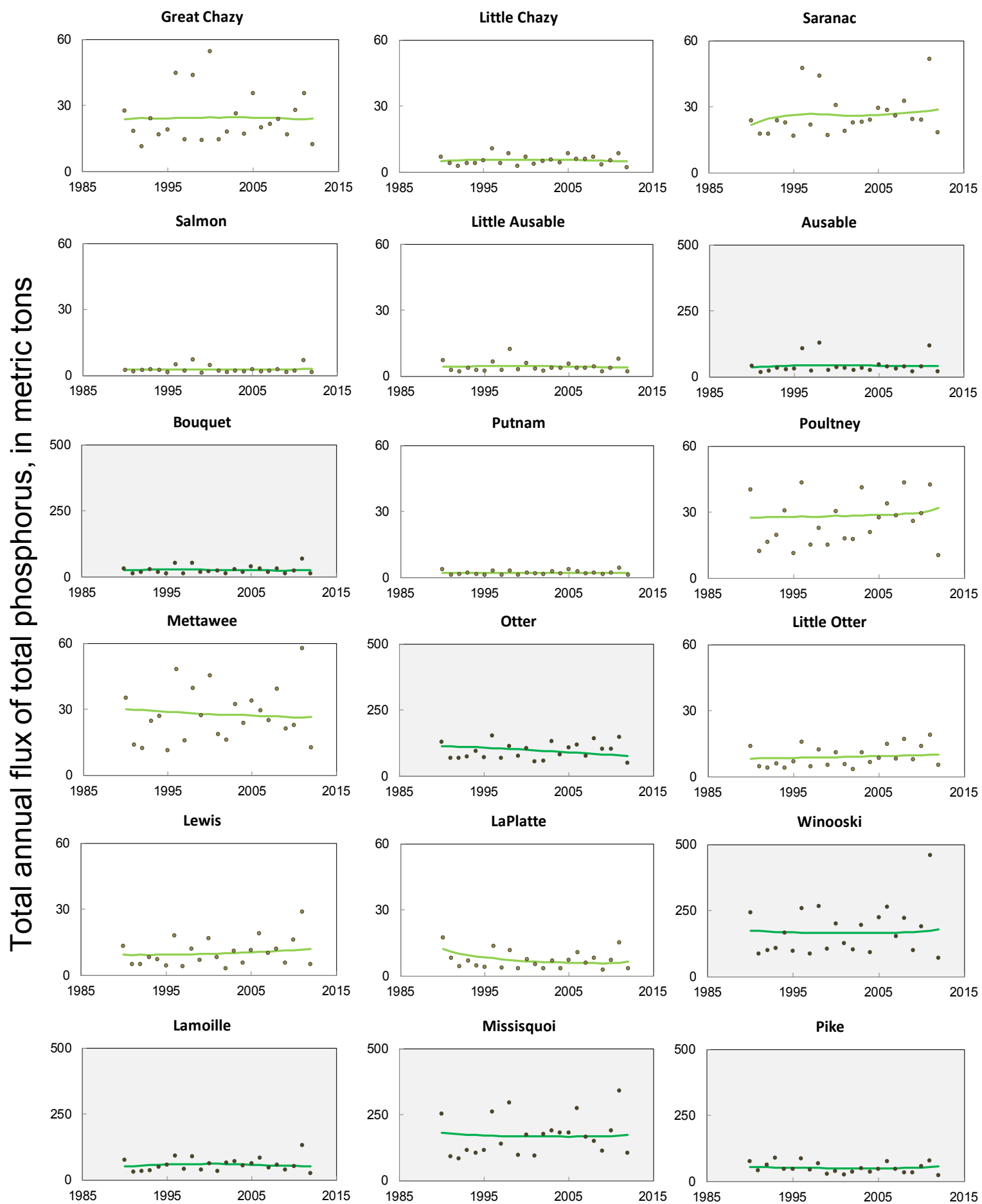

Figure 8. Graphs showing annual estimated (brown dots) and flow-normalized (green lines) flux of total phosphorus for the 18 monitored tributaries of Lake Champlain from 1990 through 2012. The y-axis scales for the shaded plots are different than the rest of the plots. 

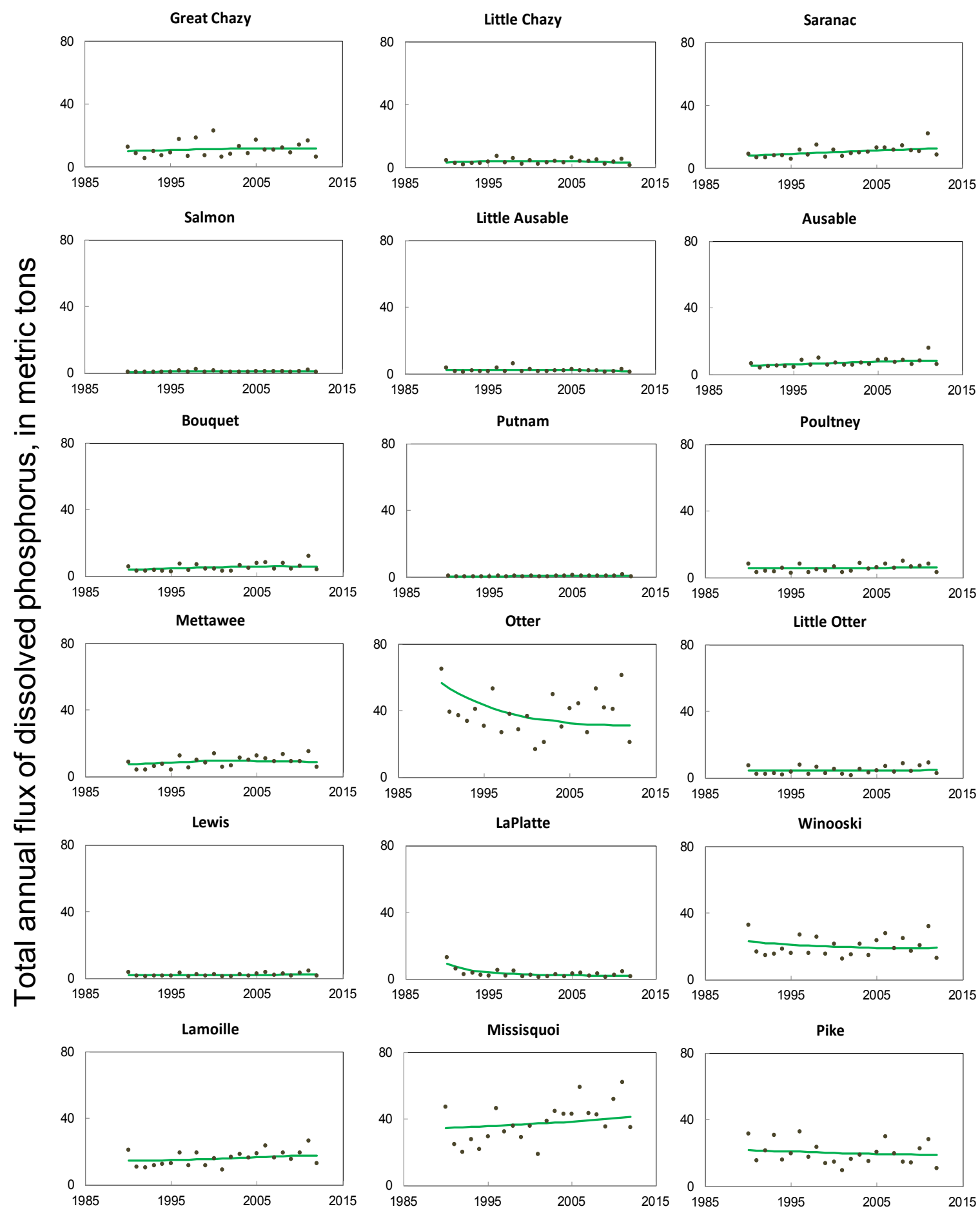

Figure 9. Graphs showing annual estimated (brown dots) and flow-normalized (green lines) flux of dissolved phosphorus for the 18 monitored tributaries of Lake Champlain from 1990 through 2012. 

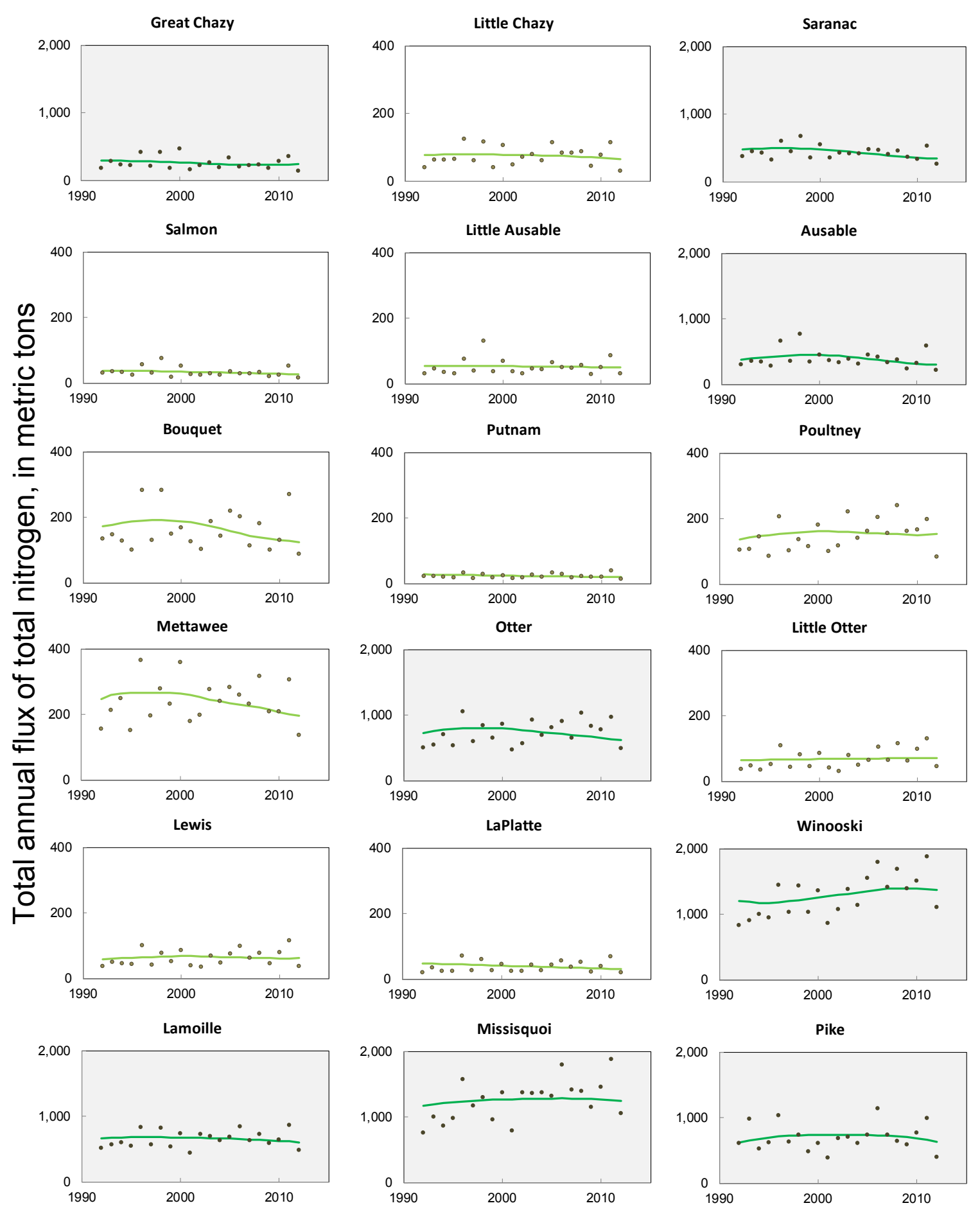

Figure 10. Graphs showing annual estimated (brown dots) and flow-normalized (green lines) flux of total nitrogen for the 18 monitored tributaries of Lake Champlain from 1992 through 2012. The y-axis scales for the shaded plots are different than the rest of the plots. 

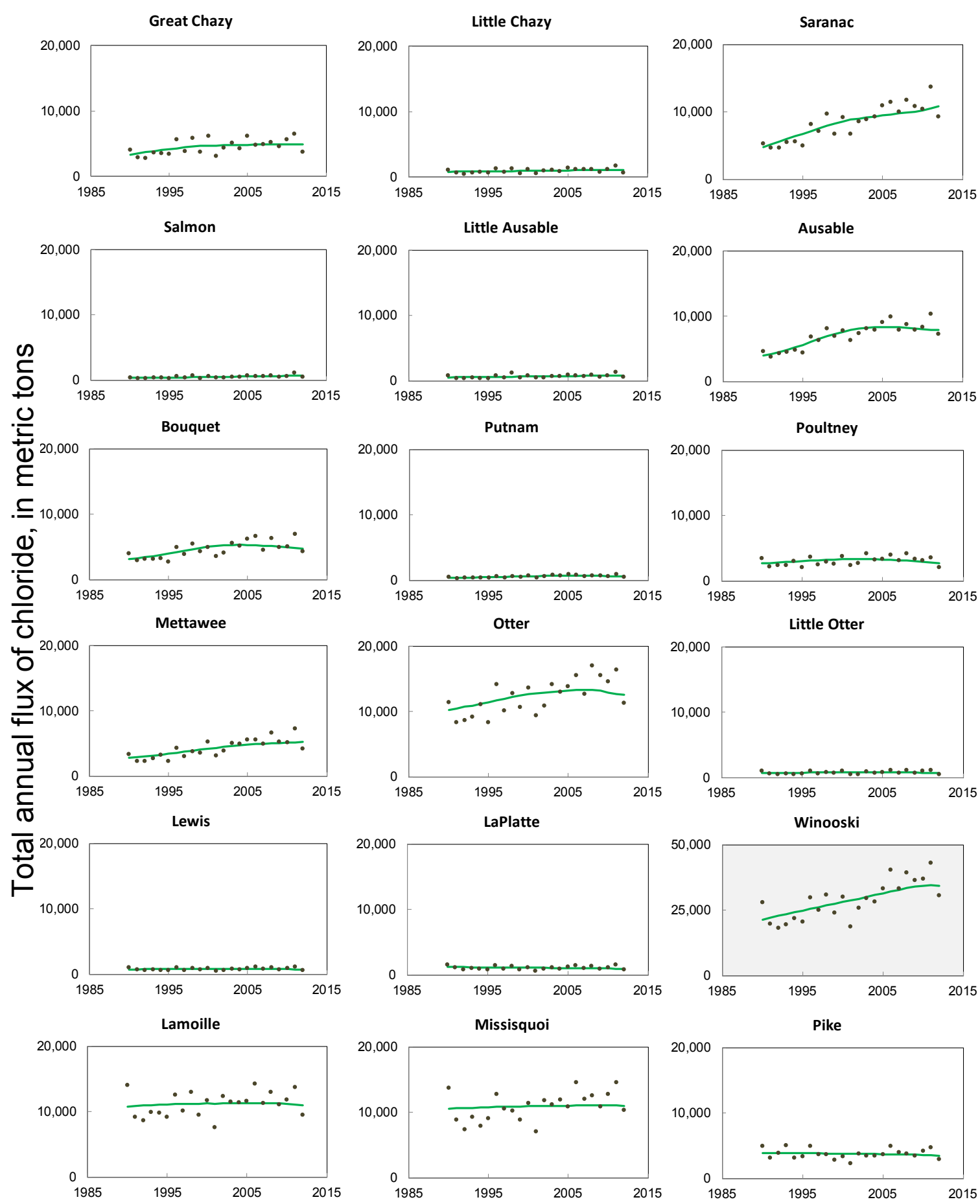

Figure 11. Graphs showing annual estimated (brown dots) and flow-normalized (green lines) flux of chloride for the 18 monitored tributaries of Lake Champlain from 1990 through 2012. The y-axis scale for the Winooski River plot is different than the rest of the plots. 

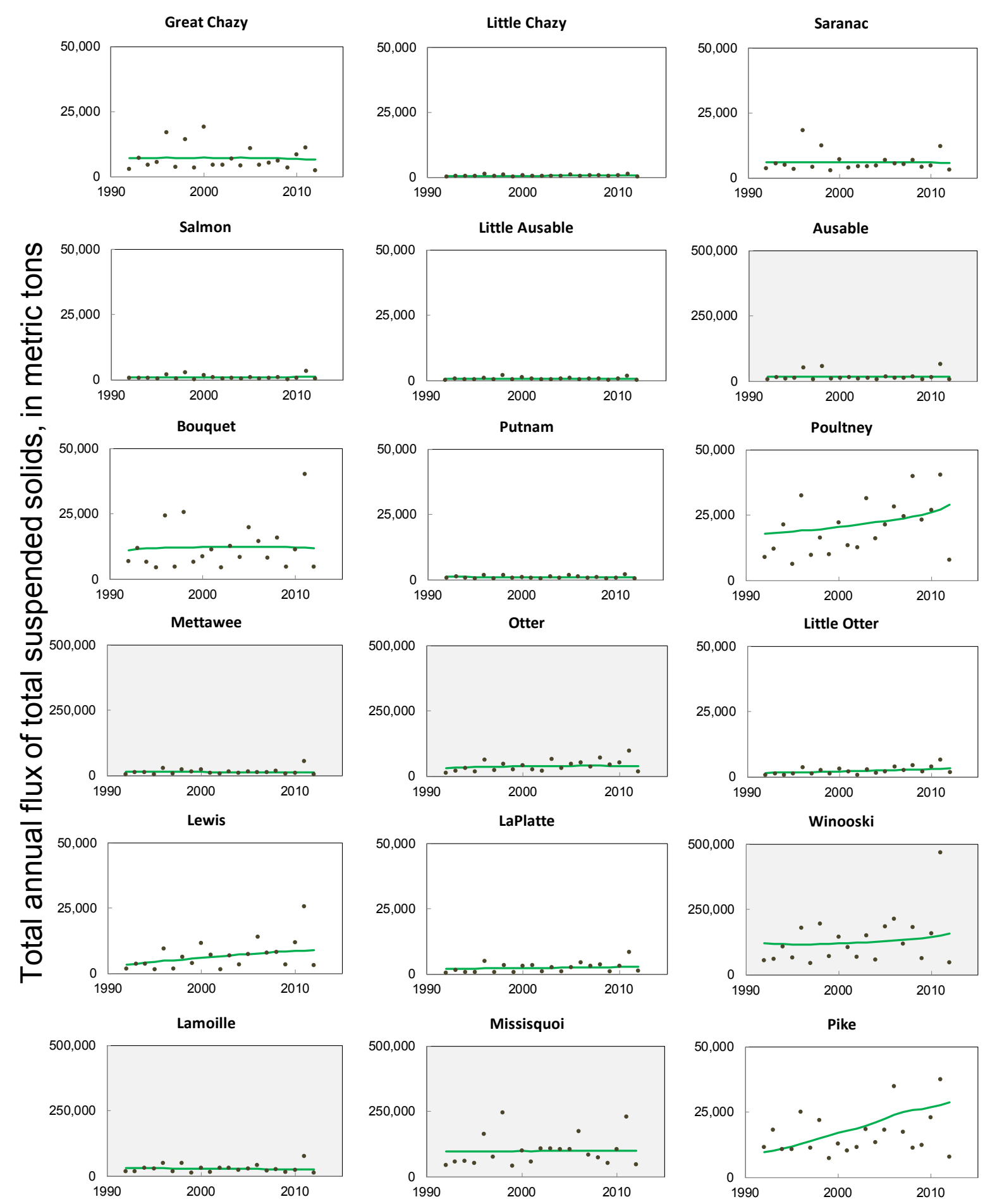

Figure 12. Graphs showing annual estimated (brown dots) and flow-normalized (green lines) flux of total suspended solids for the 18 monitored tributaries of Lake Champlain from 1992 through 2012. The y-axis scales for the shaded plots are different than the rest of the plots. 
Table 1. Streamgage and water-quality monitoring station numbers and drainage areas for tributaries to Lake Champlain.

[USGS, U.S. Geological Survey; MENV, Ministry of the Environment (Quebec, Canada); km², square kilometers; NY, New York; VT, Vermont; QU, Quebec; tributaries are listed in downstream order]

\begin{tabular}{|c|c|c|c|c|}
\hline \multirow[b]{2}{*}{ Tributary name } & \multirow{2}{*}{$\begin{array}{l}\text { State or } \\
\text { province }\end{array}$} & \multirow{2}{*}{$\begin{array}{c}\text { USGS or MENV } \\
\text { streamgage number }\end{array}$} & \multicolumn{2}{|c|}{ Drainage area } \\
\hline & & & $\begin{array}{c}\text { At streamgage } \\
\left(\mathrm{km}^{2}\right)\end{array}$ & $\begin{array}{c}\text { At tributary outlet } \\
\left(\mathrm{km}^{2}\right)\end{array}$ \\
\hline Great Chazy & NY & 04271500 & 629 & 774 \\
\hline Little Chazy & NY & 04271815 & 129 & 137 \\
\hline Saranac & NY & 04273500 & 1,575 & 1,590 \\
\hline Salmon & NY & 04273700 & 163 & 176 \\
\hline Little Ausable & NY & 04273800 & 176 & 189 \\
\hline Ausable & NY & 04275500 & 1,155 & 1,329 \\
\hline Bouquet & NY & 04276500 & 699 & 704 \\
\hline Putnam & NY & 04276842 & 135 & 161 \\
\hline Poultney & $\mathrm{VT} / \mathrm{NY}$ & 04280000 & 484 & 681 \\
\hline Mettawee & $\mathrm{VT} / \mathrm{NY}$ & 04280450 & 433 & 1,098 \\
\hline Otter & VT & 04282500 & 1,627 & 2,445 \\
\hline Little Otter & VT & 04282650 & 148 & 189 \\
\hline Lewis & VT & 04282780 & 199 & 210 \\
\hline LaPlatte & VT & 04282795 & 117 & 137 \\
\hline Winooski & VT & 04290500 & 2,704 & 2,753 \\
\hline Lamoille & VT & 04292500 & 1,777 & 1,873 \\
\hline Missisquoi & VT/QU & 04294000 & 2,201 & 2,240 \\
\hline Pike $^{1}$ & QU/VT & 030420 & 404 & 668 \\
\hline Pike $^{1}$ & QU/VT & 030424 & 584 & 966 \\
\hline
\end{tabular}

${ }^{1}$ Because neither of the Pike River stations had a continuous discharge record from 1990 through 2012, the record from streamgage 030420 was used to reconstruct the record for streamgage 030424 for the missing period from January 1990 through October 2001. 
Table 2. Half-window widths for parameters of the Weighted Regression on Time, Discharge, and Season (WRTDS) regression model used to estimate concentration and flux of total and dissolved phosphorus, total nitrogen, chloride, and total suspended solids for tributaries to Lake Champlain.

[Time is in number of years; discharge is in logarithm cycles ${ }^{1}$; season is in fraction of years. The Weighted Regression on Time, Discharge, and Season regression model is from Hirsch and others (2010)]

\begin{tabular}{|c|c|c|c|c|c|c|c|c|c|c|c|c|c|c|c|}
\hline \multirow{2}{*}{ Tributary } & \multicolumn{3}{|c|}{ Total phosphorus } & \multicolumn{3}{|c|}{ Dissolved phosphorus } & \multicolumn{3}{|c|}{ Total nitrogen } & \multicolumn{3}{|c|}{ Chloride } & \multicolumn{3}{|c|}{ Total suspended solids } \\
\hline & Time & Discharge & Season & $\overline{\text { Time }}$ & Discharge & Season & $\overline{\text { Time }}$ & Discharge & Season & Time & Discharge & Season & $\overline{\text { Time }}$ & Discharge & Season \\
\hline Great Chazy & 20 & 2 & 0.5 & 20 & 2 & 0.5 & 10 & 3 & 0.5 & 10 & 2 & 0.5 & 20 & 2 & 0.5 \\
\hline Little Chazy & 20 & 2 & 0.5 & 20 & 2 & 0.5 & 20 & 3 & 0.5 & 20 & 2 & 0.5 & 20 & 2 & 0.5 \\
\hline Saranac & 10 & 2 & 0.5 & 20 & 2 & 0.5 & 10 & 3 & 0.5 & 10 & 2 & 0.5 & 20 & 2 & 0.5 \\
\hline Salmon & 10 & 3 & 0.5 & 20 & 2 & 0.5 & 20 & 2 & 0.5 & 20 & 2 & 0.5 & 20 & 3 & 0.5 \\
\hline Little Ausable & 20 & 2 & 0.5 & 20 & 2 & 0.5 & 20 & 3 & 0.5 & 20 & 2 & 0.5 & 20 & 2 & 0.5 \\
\hline Ausable & 15 & 2 & 0.5 & 20 & 2 & 0.5 & 10 & 2 & 0.5 & 10 & 2 & 0.5 & 20 & 2 & 0.5 \\
\hline Bouquet & 10 & 2 & 0.5 & 20 & 2 & 0.5 & 10 & 2 & 0.5 & 10 & 3 & 0.5 & 20 & 2 & 0.5 \\
\hline Putnam & 20 & 2 & 0.5 & 10 & 2 & 0.5 & 10 & 2 & 0.5 & 10 & 2 & 0.5 & 20 & 2 & 0.5 \\
\hline Poultney & 20 & 3 & 1 & 20 & 3 & 0.5 & 10 & 3 & 0.5 & 10 & 2 & 0.5 & 20 & 2 & 0.5 \\
\hline Mettawee & 20 & 2 & 0.5 & 10 & 3 & 0.5 & 10 & 3 & 0.5 & 10 & 2 & 0.5 & 20 & 2 & 0.5 \\
\hline Otter & 20 & 2 & 0.5 & 10 & 2 & 0.5 & 10 & 2 & 0.5 & 10 & 2 & 0.5 & 20 & 2 & 0.5 \\
\hline Little Otter & 20 & 2 & 0.5 & 10 & 2 & 0.5 & 20 & 2 & 0.5 & 10 & 2 & 0.5 & 30 & 3 & 0.5 \\
\hline Lewis & 20 & 2 & 0.5 & 30 & 3 & 0.5 & 10 & 3 & 0.5 & 10 & 2 & 0.5 & 20 & 2 & 0.5 \\
\hline LaPlatte & 10 & 2 & 0.5 & 10 & 2 & 0.5 & 20 & 3 & 0.5 & 20 & 3 & 0.5 & 10 & 2 & 0.5 \\
\hline Winooski & 20 & 2 & 0.5 & 20 & 2 & 0.5 & 10 & 3 & 0.5 & 20 & 2 & 0.5 & 20 & 2 & 0.5 \\
\hline Lamoille & 10 & 2 & 0.5 & 20 & 3 & 0.5 & 20 & 3 & 0.5 & 20 & 3 & 1 & 20 & 2 & 0.5 \\
\hline Missisquoi & 20 & 2 & 0.5 & 30 & 3 & 0.5 & 20 & 3 & 1 & 30 & 3 & 0.5 & 30 & 3 & 0.5 \\
\hline Pike & 20 & 2 & 0.5 & 20 & 3 & 0.5 & 20 & 3 & 0.5 & 20 & 2 & 0.5 & 10 & 3 & 1 \\
\hline
\end{tabular}

${ }^{1}$ One logarithm cycle means that discharge differs by a factor of 10 ; for two and three logarithm cycles, the factors are 100 and 1,000 . 
Table 3. Flux bias statistics comparing the Weighted Regressions on Time, Discharge, and Season regression model estimates with water-quality observations for total and dissolved phosphorus, total nitrogen, chloride, and total suspended solids for tributaries to Lake Champlain.

[Flux bias statistics greater than \pm 0.1 are bolded and indicate a potentially biased regression model. The Weighted Regression on Time, Discharge, and Season regression model is from Hirsch and others (2010)]

\begin{tabular}{lccccc}
\hline \multicolumn{1}{c}{ Tributary } & Total phosphorus & $\begin{array}{c}\text { Dissolved } \\
\text { phosphorus }\end{array}$ & Total nitrogen & Chloride & $\begin{array}{c}\text { Total suspended } \\
\text { solids }\end{array}$ \\
\hline Great Chazy & -0.005 & 0.022 & 0.008 & -0.018 & $\mathbf{0 . 1 8 8}$ \\
Little Chazy & -0.010 & -0.039 & -0.015 & -0.020 & 0.051 \\
Saranac & $\mathbf{- 0 . 3 0 5}$ & $\mathbf{- 0 . 1 5 1}$ & -0.020 & -0.033 & $\mathbf{- 0 . 8 3 9}$ \\
Salmon & -0.031 & 0.015 & -0.026 & -0.015 & 0.072 \\
Little Ausable & -0.096 & $\mathbf{- 0 . 1 0 8}$ & 0.023 & -0.023 & $\mathbf{0 . 1 2 2}$ \\
Ausable & 0.071 & -0.045 & -0.030 & -0.019 & $\mathbf{0 . 1 7 8}$ \\
Bouquet & 0.060 & 0.050 & 0.082 & -0.029 & $\mathbf{0 . 2 7 3}$ \\
Putnam & $\mathbf{- 0 . 1 2 5}$ & -0.025 & -0.043 & -0.052 & -0.033 \\
Poultney & 0.031 & -0.002 & -0.023 & -0.010 & 0.062 \\
Mettawee & 0.083 & 0.017 & -0.016 & -0.003 & $\mathbf{0 . 1 2 5}$ \\
Otter & -0.001 & 0.008 & -0.033 & -0.024 & 0.005 \\
Little Otter & 0.014 & 0.018 & 0.003 & -0.020 & 0.030 \\
Lewis & -0.024 & -0.060 & -0.017 & -0.006 & 0.003 \\
LaPlatte & 0.058 & 0.074 & 0.011 & 0.009 & 0.073 \\
Winooski & 0.020 & -0.004 & -0.020 & -0.029 & 0.052 \\
Lamoille & -0.085 & 0.009 & -0.017 & -0.023 & $\mathbf{- 0 . 1 4 7}$ \\
Missisquoi & 0.023 & 0.011 & -0.017 & -0.018 & 0.039 \\
Pike & 0.004 & 0.034 & -0.049 & -0.023 & 0.001 \\
\hline
\end{tabular}



Prepared by the Pembroke Publishing Service Center.

For more information concerning this report, contact:

\section{Office Chief}

New Hampshire-Vermont Office

New England Water Science Center

U.S. Geological Survey

331 Commerce Way, Suite 2

Pembroke, NH 03275

dc_nh@usgs.gov

or visit our Web site at:

http://nh.water.usgs.gov 
